\title{
The Problem-Oriented Analysis of Regional Cluster Policy Development in the Russian Federation
}

\author{
Tamara Tavinovna Tsathlanova \\ Danara Vladimirovna Idzhilova \\ Elsata Viktorovna Erdnieva
}

Kalmyk State University, The Republic of Kalmykia, 358000, Elista, street Pushkin, 11

\section{Doi:10.5901/mjss.2015.v6n4p333}

\begin{abstract}
Industrial clusters are actively developing in many regions of the world. This is entailed by the massive opportunities for economic growth and a number of positive multiplier effects. The world experience confirms that cluster strategy is an important step towards the overall development of areas and economic sectors. In Russia, one can see a transition from the conceptual framework of policy to practical measures aimed at supporting cluster initiatives. At the same time, foreign tools used in Russian environment require a thorough analysis of real barriers that limit the efficiency of innovative development program.
\end{abstract}

Keywords: regional economics; cluster policy; cluster.

\section{Introduction}

It is very important for regional cluster policy to detect and comprehend the urgent problem of sustainable and dynamic development of a country and the whole society.

Problem is the difference between a desired condition of some system (sphere) and the normatively required condition. Problem can be measured by quantitative and qualitative relations in a form of the desired result. This unites problem with goals and tasks. However, problem is at first place in the hierarchy of results. The second is goal because it is formulated during the detection and comprehension of problem. Tasks are at third place because state body, while solving tasks, achieves the goal or comes close to it. Then it reduces the acuteness of a problem in its field of activity [2]

One of the key elements in the development of regional clusters is to detect and assess the most urgent problems. No state body can solve all the problems in regional cluster policy at once because of a lack of time, money, personnel and inventory, and also the influence of external environment [1].

Goal formulation is also a very important process after problem detection and comprehension. In the general management theory, there is a proposition that any management process begins with goal formulation i.e. the determination of result or a state of management object that management subject strives for.

\section{Methods}

The flexibility and efficiency of management consists in the ability to define correctly not only the long-term goals but also the closest ones and to establish the priorities of tasks for defined goals.

During the research, we will detect the factors which on the one hand are a stimulating component and on the other hand prevent the development of clusters in economics.

The assessment of problems in the system of regional cluster policy is based on the schemes of relations between the elements of problem tree (problem, causes and effects) and solution tree (goals, tasks and indicators). Besides, the basis of assessment contains a framework problem-oriented method for the analysis and solution of organizational and economic tasks. The purpose of this method is to formulate, in the long run, a set of tasks which can help to eliminate the problem or to moderate its acuteness. The set of such tasks is a plan or program of actions to solve the problem [5]

Every problem has its causes and effects. Each of causes, in its turn, has its own causes (the problems of lower level). It comes out that every problem can be presented as a tree of problems. Effects are problems too. They can also be shown as a tree. 
Every problem solution can be presented as a tree of solutions, or a set of goals, tasks and indicators. It comes out that the tree of solutions is an "inverted" tree of problems.

The number of levels in the tree of problems is determined by the specificity of conducted research and individual ideas of its authors.

"Framework method" means that the applied method is just a set of stages and phases of research without stepby-step disclosing of techniques for certain stages. The stages and phases of this method can be carried out with the help of well-known expert and analytic methods, such as questioning for experts; brainstorm; business games; "round table" on the topic; the study of publications, etc.

Table 1. The framework problem-oriented method for the analysis and solution of organizational and economic tasks

\begin{tabular}{|c|c|c|}
\hline Stage & Phase & Comments \\
\hline \multirow{3}{*}{$\begin{array}{l}\text { Constructing } \\
\text { a tree of } \\
\text { problems }\end{array}$} & 1.1. Formulating the main problem & The description of differences between the real and desired situation \\
\hline & 1.2. Detecting the effects of the problem & Detailing the real situation. The description of negative effects it can cause. \\
\hline & 1.3. Detecting the causes of the problem & $\begin{array}{l}\text { Causes are problems too, but of another level. Constructing a tree of problems. The } \\
\text { assessment of possibilities to solve them on the basis of Russian and foreign experience. }\end{array}$ \\
\hline \multirow{3}{*}{$\begin{array}{l}\text { Constructing } \\
\text { a tree of } \\
\text { solutions }\end{array}$} & 1.1. Formulating a goal for problem solution & The goal of solution is to eliminate the problem. \\
\hline & 1.2. Defining the tasks & Task solution is aimed at eliminating the problem of the next level. Constructing a tree of solutions. \\
\hline & $\begin{array}{l}\text { 1.3. Defining the indicators for problem } \\
\text { solutions }\end{array}$ & $\begin{array}{l}\text { Indicators are to show how solution "ends" the problem, minimizes its negative effects and } \\
\text { brings the situation closer to the desired condition. }\end{array}$ \\
\hline
\end{tabular}

The main problem is formulated, and the causes and possible effects of this problem are listed in any form. Then, with the help of analytic methods, the causes and effects are ranked by their importance and their influence on the acuteness of the main problem or on the efficiency of its solution [3].

Figure 2 shows the tree of problems arising during the development of regional clusters. The causes (problems), which impede the development of regional clusters, are divided into three groups: economic, organizational and sociopolitical ones. The effects of existing problems are grouped into the following sets: economic, technical and social ones.

\section{Main Part}

The majority of cluster experts note that "cluster policy" is based on such economic indicator as "competition". This is a very important indicator which helps to assess the economic condition of a country and its future development. System crisis involved almost all countries and created conditions for clusters to significantly affect the formation of national and regional competitiveness.

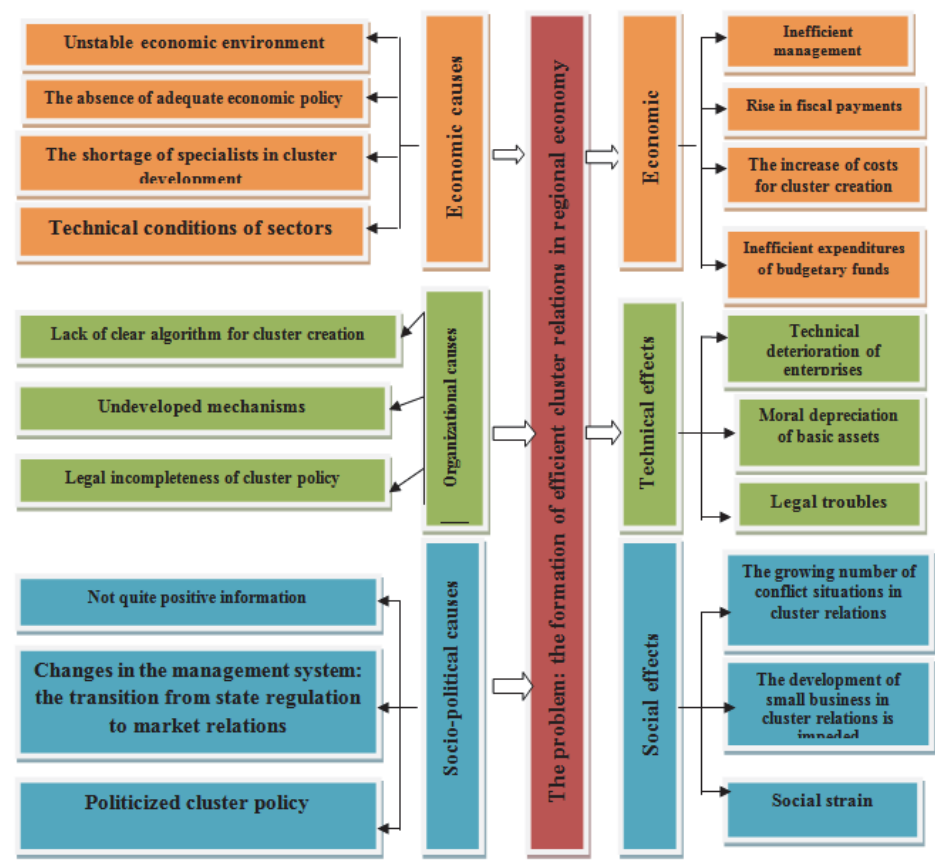

Figure 1. The structure of problems arising during the formation of regional cluster policy 
As practice shows the economic growth in Russia is still achieved first of all at the expense of natural resources and less on the basis of balanced policy.

Table 2. The main target strategic indicators for the sustainable economic development of Russia until 2020 [2]

\begin{tabular}{|c|c|c|c|c|}
\hline Tasks & Indicators & Unit & 2011 & 2020 \\
\hline \multirow{2}{*}{$\begin{array}{l}\text { To diversify the economy and increase its } \\
\text { competitiveness }\end{array}$} & $\begin{array}{l}\text { The share of hi-tech and knowledge-intensive industries } \\
\text { in GDP }\end{array}$ & $\%$ & 3.4 & 4.4 \\
\hline & The level of competitiveness of the national economy & \multirow{2}{*}{$\begin{array}{l}\text { Position in global } \\
\text { rating }\end{array}$} & 66 & 50 \\
\hline To improve the climate for business and investments & The level of business comfort & & 120 & $50-60$ \\
\hline To eliminate poverty and reduce income differences & The share of people with income below poverty line & $\%$ & 12.8 & 10.0 \\
\hline \multirow{2}{*}{ To reduce corruption } & \multirow{2}{*}{ The level of corruption perception } & Points & 2.4 & $3-4$ \\
\hline & & Position in rating & 143 & $70-80$ \\
\hline To raise the quality and efficiency of state management & The index of quality and efficiency of state management & Percentile & 41.6 & $\begin{array}{c}\text { Not less than } \\
50 \\
\end{array}$ \\
\hline \multirow{2}{*}{$\begin{array}{l}\text { To raise environmental responsibility and the energy } \\
\text { efficiency of the economy }\end{array}$} & \multirow[b]{2}{*}{ The level of ecological sustainability } & Points & 45.43 & $50-55$ \\
\hline & & $\begin{array}{l}\text { Position in global } \\
\text { rating }\end{array}$ & 106 & 80-90 \\
\hline
\end{tabular}

Efficient regional cluster policy makes for [4]:

- The sociology of innovations. Here an important role is marked out in reducing transactional costs caused by strengthening specialization, increasing influence of non-financial encouragement and barter in innovation networks and the contribution of institutional and culture diversity to creativity;

- The evolution character of economy. As it is known, knowledge acquisition depends on the previous period of development. It forms directions for the interaction between commercial and noncommercial organizations and various institutions;

- The new theory of economic growth. Here the importance belongs to increasing output from accumulated knowledge based, in its turn, on investments in human capital and new technologies;

- Further institutionalization of economy. Within its framework, we emphasize the importance of organizational novelties inside companies and state bodies in establishing and coordinating institutions and procedures involved in cluster management.

The newest trend in Russian economic policy is "The Strategy 2020" and the Russian Federation Presidential Decree of May 7, 2012 \# 596 "On the long-term state economic policy".

The main goals of these documents are:

- to diversify the economy and increase its competitiveness;

- $\quad$ to improve the climate for business and investments;

- to eliminate poverty and reduce income differences;

- to reduce corruption;

- $\quad$ to raise the quality and efficiency of state management;

- to raise environmental responsibility and the energy efficiency of the economy.

The modern condition of Russia is confirmed by "The Global Competitiveness Report" issued by the analytical group of World Economic Forum. It allows evaluating the competitiveness of economy [1].

The experts of World Economic Forum note serious advantages in certain factors, especially in science, technology, manpower resources and physical facilities. This is a strong potential for cluster policy formation.

Table 3. The competitiveness of Russian economy

\begin{tabular}{|l|l|}
\hline Positive changes & Drawbacks \\
\hline Dynamic economic growth; & $\begin{array}{l}\text { Economic growth was carried out at the expense of extractive } \\
\text { industries (oil and gas); } \\
\text { the growth of GDP per capita; relatively strong financial } \\
\text { position; improved macroeconomic management; } \\
\text { the inflow of direct foreign investments; } \\
\text { consolidated general positions on the world export market; } \\
\text { accession to the WTO. }\end{array}$ \\
$\begin{array}{l}\text { world prices of natural resources (oil); } \\
\text { low labour productivity; direct foreign investments were first of all sent } \\
\text { to extractive industries; } \\
\text { weak positions in export not connected with natural resources; } \\
\text { moral and physical depreciation of fixed assets. }\end{array}$ \\
\hline
\end{tabular}


As before, the biggest weaknesses in Russian economy include corruption, access to financing and tax regulation. Such barriers as state machine's inefficiency and the crime rate have the top positions.

All these problems prevent Russia from using its competitive advantages, such as relatively low government debt, low budget gap, large volume of market, relatively high innovative potential and high-quality education.

It would be fair to say that the state stirs up its policy with the imperative of the transition to innovative industrial development and uses a wide spectrum of conditions and methods tested in world practice. Particularly, it uses cluster policy.

The essence of cluster policy implemented by state bodies is one of the most important parts of the regional strategy. Regional cluster policy has a number of peculiarities. For instance, the moment when enterprises are chosen for cluster interaction is followed by cooperation processes both inside the system and outside it. Besides, it is necessary to understand that the participants (enterprises) of a cluster are in different phases of life cycle. After clustering (integration) begins, all participants get into the phase of formation having different start conditions. This can impede the development [7]. Experience shows the following causes of it:

- the low quality of organizational design displayed by all participants (authorities and commerce) of the future cluster;

- $\quad$ an insufficient regard for the opportunities of all cluster entities;

- $\quad$ the applied model does not correspond to the goals of the cluster.

Generally, regional cluster should be considered as a synergetic alliance of enterprises allowing them to consolidate their competitive positions and to obtain financial and other advantages in business development. By analyzing this thesis, one can make a conclusion that a considered and efficient cluster policy carried out by regions can change the market structure for the better. Besides, big enterprises will encourage small business which in its turn will take prompt actions that will strengthen their positions [4].

It is known that the main reason for the negative economic development of the Republic of Kalmykia is the dullness of its basic economic activities. Thus the principal guideline for cluster policy here should consist in their restoration and consolidation. The results of the SWOT-analysis for basic economic activities are presented in Table 4.

Table 4. The results of the SWOT-analysis for the basic economic activities of the Republic of Kalmykia

\begin{tabular}{|c|l|l|}
\hline Competitive position & Economic activities & The characteristics of economic activities \\
\hline Strong & Agricultural livestock production & Quite stable with growth areas \\
\hline \multirow{2}{*}{ Limited } & $\begin{array}{l}\text { The production and distribution of wind energy; } \\
\text { raw hydrocarbons extraction; construction; food } \\
\text { production. }\end{array}$ & $\begin{array}{l}\text { Relatively strong position. Their growth } \\
\text { prospects are basically limited by national } \\
\text { factors. }\end{array}$ \\
\hline
\end{tabular}

The results of the analysis make it possible to ascertain that the category of strong industries include agricultural livestock production. However, in the author's opinion, their potential, including the export potential, is still not used enough. The production and distribution of wind energy, raw hydrocarbons extraction, construction and food production are not of the region's specialization but they have a potential opportunity to enter this group in the offing. Their regional components have a positive trend [8].

The balanced territorial development of Kalmykia presupposes the fulfillment of conditions allowing each municipal unit to have all necessary resources for worthy life of people, complex development and the improvement of competitiveness of the Republic's economy.

The balanced socio-economic development of municipal units as one of the target guidelines for the socioeconomic development of the Republic of Kalmykia requires synchronizing such objectives of the territorial policy as:

- To stimulate economic development by creating new centres of economic growth in municipal units on the basis of competitive advantages;

- To coordinate infrastructure investments of budget and non-budget character in municipal units with a glance to the priorities of spatial development and resource limits;

- To reduce differentiation in the level and quality of people's life in the Republic using the effective mechanisms of social and budget policy.

One of the main tasks for territorial development is to create city conditions in regional centres. This will solve the problem of people outflow from rural areas. Moreover, the development of rural areas is a strategic component for the security of Russia [9]. 
The prospective spatial development of the Republic is connected with the formation and work of a sound territorial framework from the existing and new centres of innovative economic growth on the basis of a multipolar approach. Economic centres will form territories around themselves with a potential for accelerated development, relative to surrounding areas, in the mid-run. These will be zones of economic development where basic and prospective sectors, infrastructure and industrial cluster areas will develop rapidly.

In the assigned zones, there will be development conditions for the clusters of enterprises with prospective specializations and a good development potential [12].

He cluster approach can fundamentally change the content of territorial policy. In this case, the efforts of government will be directed not to supporting certain enterprises and sectors but to the development of inter relations between suppliers and customers, between ultimate consumers and manufacturers and between manufacturers and state bodies [10].

Table 5. The formation of areas with advanced development in the Republic of Kalmykia on the basis of the cluster approach

\begin{tabular}{|l|l|l|}
\hline Cluster & Regions & Characteristics \\
\hline $\begin{array}{l}\text { The zone of oil and gas } \\
\text { processing industry }\end{array}$ & Chernozemel'sky and Lagansky regions & $\begin{array}{l}\text { Vast reserves of raw hydrocarbons; favourable climate conditions } \\
\text { for fishing and fish breeding; advantageous transport position. }\end{array}$ \\
\hline $\begin{array}{l}\text { The zone of energy and } \\
\text { construction }\end{array}$ & Yashkul'sky, Iki-Burul'sky and Priyutnensky regions & $\begin{array}{l}\text { A significant wind potential and general-use mineral resources } \\
\text { (sand, gravel, clay, shell rock); construction material production. }\end{array}$ \\
\hline $\begin{array}{l}\text { The zone of beef farming } \\
\text { and feed industry }\end{array}$ & $\begin{array}{l}\text { Orkyabr'sky, Maloderbetovsky, Sarpinsky, } \\
\text { Ketchenerovsky, Tselinny, Yustinsky, Gorodovikovsky } \\
\text { and Yashaltinsky regions }\end{array}$ & $\begin{array}{l}\text { The development of certain agricultural areas (plant cultivation; } \\
\text { beef, milk and wool husbandry). }\end{array}$ \\
\hline
\end{tabular}

In Kalmykia, there are three conventional zones of advanced development: the zone of oil and gas processing industry occupies the areas of Chernosemel'sky and Lagansky regions. The zone of energy and construction includes the areas of Yashkul'sky, Iki-Burul'sky and Priyutnensky regions. The zone of beef farming and feed industry involves the areas of Orkyabr'sky, Maloderbetovsky, Sarpinsky, Ketchenerovsky, Tselinny, Yustinsky, Gorodovikovsky and Yashaltinsky regions. Clusters were identified as the zones of advanced development on the basis of specialization formed in the area:

The zone of oil and gas processing industry is characterized by the vast reserves of raw hydrocarbons, favourable climate conditions for fishing and fish breeding and advantageous transport position.

The zone of energy and construction is characterized by a significant wind potential, general-use mineral resources (sand, gravel, clay, shell rock) and construction material production.

The zone of beef farming and feed industry is specialized in the development of certain agricultural sectors (plant cultivation; beef, milk and wool husbandry).

For the prospective balance of economy in the Republic of Kalmykia, within the framework of cluster policy development, there are the following innovation-oriented clusters proposed:

1. Animal husbandry (Ketchenerovsky, Yashkul'sky and Maloderbetovsky regions);

2. Plant cultivation (Gorodovikovsky and Yashaltinsky regions);

3. Fish processing (Lagansky region);

4. Oil and gas (Chernozemel'sky and Lagansky regions);

5. Energy (Priyutnensky region);

6. Industrial: production of construction materials(Iki-Burul'sky, Yashkul'sky regions);

7. Tourism and recreation (Yustinsky, Yashaltinsky and Lagansky regions).

One of the key guidelines for the socio-economic development of the Republic is to increase the investment attractiveness of the region.

It should be noted that Russian scientific society takes an active part in the development of cluster policy in Russian regions. For instance, the National Research University "The Higher School of Economics" lobbies for its own cluster development projects. On the basis of worked out methods, they lobby and in effect implement the Government Resolution \# 188 of March 6, 2013 "On the approval of the Rules for Budget Subsidies Provided for Pilot Innovative Territorial Clusters". Besides, the University has its own web-site called "Russian Cluster Observatory" created to attract the attention of local authorities to clusters [11].

So, practice shows that cluster policy should be considered as a purposeful and effective process in which a number of organizational and economic measures should be included. Here are some of its features:

- $\quad$ Cluster is created by transforming the existing economic entities. That is why it is necessary to take their start 
conditions into account (location, assets, market share, price policy, etc.);

- $\quad$ When cluster is formed, it needs a certain period of time to fix the changes;

- $\quad$ Cluster measures touches upon all levels of management hierarchy, change the existing connections and organizational culture. All this cannot go on without conflicts. Thus a number of measures are necessary to reduce the resistance.

- Moreover, the efficient cluster policy carried out by local authorities should:

- have clear goals and tasks linked to the time of implementation;

- separate the goals and tasks of intended cluster relations from the goals and tasks of current activity of cluster participants;

- $\quad$ single out the administrative unit (core) of a cluster which control the changes and is responsible for results;

- implement completely the principles of cluster, such as the unity of interests; economic expediency; the continuity of development; adaptability, etc.

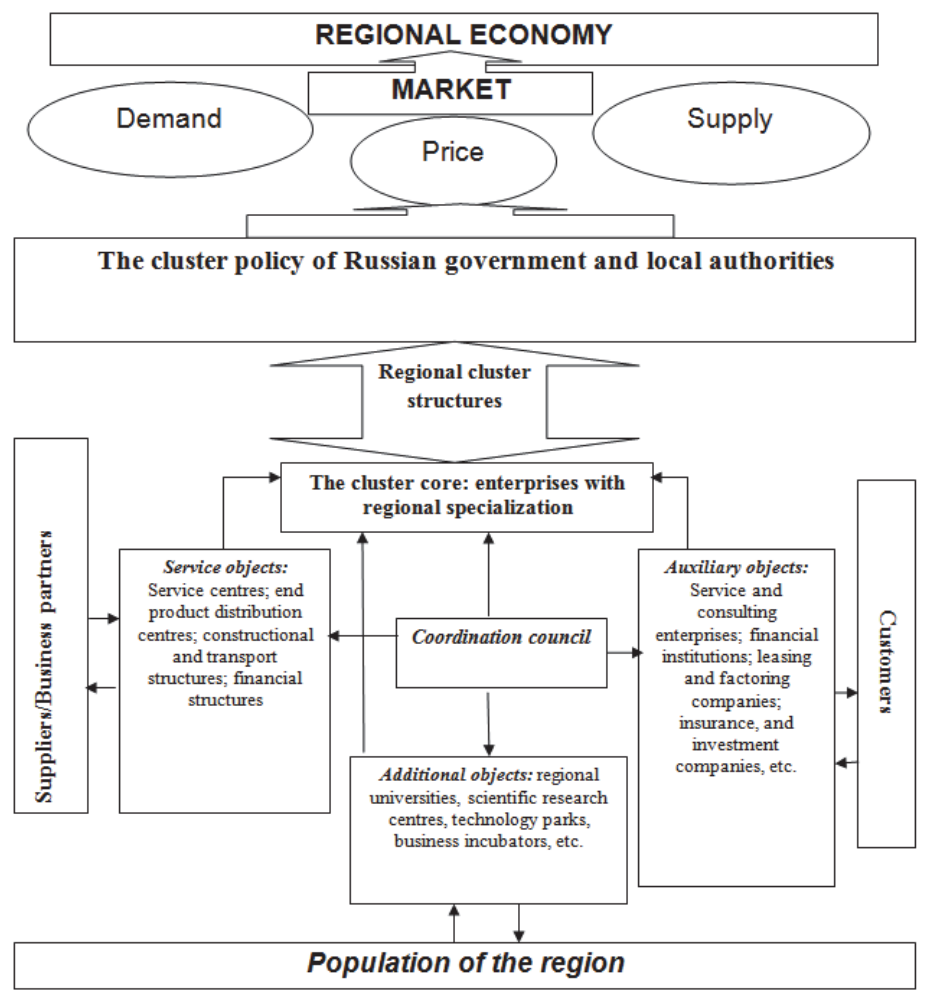

Figure 2. The model of a regional cluster

\section{Conclusion}

So, regional cluster policy should be based on a notion of "cluster" as:

- a territorial functionally compact chain of added value formation in one or several sectors;

- a mechanism to control and stimulate the economic and social development of a Russian region, i.e. cluster initiative.

Effectively considered cluster policy allows increasing the competitiveness of regional economy by providing it with a unique profile (in national scale) and stimulates the growth at the expense of new investments, innovations and scientific-technical progress [6].

In Russia, there should be a clear policy for the creation and development of regional clusters in the form of associations and consortium of enterprises and institutions which will provide localization in the area of links forming the technological chain (the chain of added value formation), the effective mobilization of resources in the area, its competitiveness and integrated development.

Besides, individual cluster policy in a certain region will help Russia to summarize the best foreign experience in applying new tools. We will do it below. 


\section{References}

Ketels, C., 2003. The Development of the Cluster Concept - Present Experiences and Further Developments. Harvard Business School research paper, pp: 25. www.isc.hbc.edu/pdf/Frontiers_of_Clusters_Research_2003.11.23.pdf.

Peters L., 2011. Presentation and interpretation of first results. OECD clusters focus group workshop. ITEO, Limburg University, Belgium, pp: 116.

Porter, M., C. Ketels and M. Delgado, 2012. The Microeconomic Foundations of Prosperity: Findings from the Business Competitiveness Index, in: World Economic Forum, The Global Competitiveness Report 2011-12, Palgrave MacMillan: New York.

Andrianov, V., 2013. The System of Well-Balanced Indicators for the Sustainable Economic Development of Russia until 2020. Society and Economics: 1-2: 11.

Yerokhina, Y., 2013. The Structure and Peculiarities of Regional Innovation System. The Problems of Theoretic and Practical Management: 2: 67-68.

Idzhilova, D.V. and G.V. Karnayeva, 2009. The Methodological Concepts for Strategic Planning in Business. The State University of Management. The University Review: 10.

Idzhilova, D.V. and N.A. Tsatkhlanova, 2009. The Efficiency of Agricultural Business. The State University of Management. The University Review: 10.

Nikitin, A., 2013. Clusteromania. The Totals: March 11, pp: 33.

Tatarkin, A. and O. Romanova, 2013. On the Possibilities and Mechanisms of Neoindustrialization of Old Industrial Regions. The Economist: 1: 34.

Kharlamova, T.L., 2011. The Business Environment Management and Cluster Policy. S.-Petersburg: The PH of the Saint-Petersburg Trade and Economic Institute, pp: 31.

Tsatkhlanova, T.T., 2012. The Role of Small Business in the Formation of Regional Business Structures. The Review of the Astrakhan State Technical University: 1. 